\title{
The Effect of Dietary Fat on the Turnover of Cholic Acid and on the Composition of the Biliary Bile Acids in Man *
}

\author{
Sven Lindstedt, Joel Avigan, DeWitt S. Goodman, $\dagger$ Jan Sjövall, and \\ DANIEl STEINBerg $\ddagger$ \\ (From the Department of Chemistry, Karolinska Institutet, Stockholm, Sweden, and the Labora- \\ tory of Metabolism, National Heart Institute, Bethesda, Md.)
}

Because of the strong influence of dietary fat on serum cholesterol levels, there has been a great deal of interest in possible parallel effects on bile acid formation and excretion. The output of bile acids in human feces has been determined in several studies by a variety of chemical and isotopic procedures. Values have been reported ranging from less than 0.1 to as high as $2 \mathrm{~g}$ per day (1-9). In several of these studies, the inclusion of unsaturated fat in the diet has been found to cause an increase in the total bile acid output, which might account for the concomitant decrease in serum cholesterol level $(1-4)$. On the other hand, in other studies, no such effect of unsaturated fat on the total bile acid output was observed $(8,10-13)$.

Direct analysis of fecal end products is beset with serious technical problems, making it difficult to obtain valid quantitative results (14). The bile acids produced in the liver (cholic acid and chenodeoxycholic acid) are radically modified by bacterial action in the intestine, giving rise to an extremely complex, heterogeneous mixture of products $(15,16)$. If changes in the diet alter the relative abundance of the several fecal bile acids, then an analysis limited to only one or a few components could give an incomplete and erroneous impression of the changes induced in total bile acid excretion.

Lindstedt (17) has previously reported an isotopic method for determination of cholic acid turnover in man based on serial measurements of the

* Submitted for publication March 25, 1965 ; accepted July 8, 1965.

The work has been supported in part by grant $\mathrm{H}-2842$ from the National Institutes of Health, Bethesda, Md., and by grants from the Swedish Medical Research Council.

$\dagger$ Present address: Dept. of Medicine, Columbia-Presbyterian Medical Center, New York, N. Y.

$¥$ Address requests for reprints to Dr. Daniel Steinberg, Chief, Laboratory of Metabolism, National Heart Institute, Bethesda, Md. 20014. declining specific radioactivity of pure cholic acid isolated from duodenal bile after oral administration of cholic acid-24- ${ }^{14} \mathrm{C}$. The main components of bile (as opposed to feces) can readily be separated by paper chromatography (14). The patterns of bile acids and their conjugates can thus be readily determined in conjunction with the isotopic studies, and estimates of the total pool of bile acids can be made. With this method, the size of the total bile acid pool and the turnover of cholic acid have been previously determined in normal young males on regular diets (17).

In the present investigation, these methods have been applied in the study of 11 patients on various types of controlled liquid formula diets or solid diets containing various amounts and types of fat.

\section{Methods}

All subjects were studied on a metabolic ward in the Clinical Center at the National Institutes of Health. Their age, sex, diagnosis, and serum lipid levels on admission are shown in Table I. Serum cholesterol was determined two or three times weekly on blood samples of fasting subjects by the method of Sperry and Webb (18). Phospholipids were determined by the method of Stewart and Hendry (19), triglycerides by the method of Bragdon (20).

The liquid formula diet contained skim milk, $40 \%$ of calories $(23.4 \%$ from carbohydrates, $16.6 \%$ from protein), and corn oil or coconut oil, $60 \%$ of calories, homogenized in water. It was administered in four daily feedings. In some studies, the subjects received a basic 5-g fat diet supplemented with oil by spoon at meal times. In other studies measured portions of the standard hospital diet were given to provide 35 to $40 \%$ of calories as fat. In all cases, total caloric intake was adjusted to maintain constant body weight.

Cholic acid-24- ${ }^{14} \mathrm{C}$ (21) ( 1 to $2 \mathrm{mg}, 2$ to $5 \mu \mathrm{c}$ ) was given orally mixed with the formula or in orange juice. In all cases, the turnover studies in each diet period were only begun after the subject had been on the diet for 1 to 2 weeks. Bile samples were obtained by duodenal intubations on the day after administration of labeled cholic acid and then at 3- to 5-day intervals. The use of an in- 
TABLE I

Age, sex, diagnosis, and serum lipid analyses of subjects at admission

\begin{tabular}{|c|c|c|c|c|c|c|c|}
\hline \multirow[b]{2}{*}{ Subject } & \multirow[b]{2}{*}{ Diagnosis } & \multirow[b]{2}{*}{ '́ge } & \multirow[b]{2}{*}{ Sex } & \multicolumn{4}{|c|}{ Serum lipid values* } \\
\hline & & & & TC & FC & PL & TG \\
\hline & & & & \multicolumn{4}{|c|}{$m g / 100 \mathrm{ml}$} \\
\hline \multirow{5}{*}{$\begin{array}{l}\mathbf{1} \\
2 \\
3 \\
4 \\
5\end{array}$} & Normal volunteer & 20 & $\mathbf{F}$ & 157 & 33 & 179 & 39 \\
\hline & Normal volunteer & 19 & $\mathbf{M}$ & 145 & 37 & 224 & 72 \\
\hline & Normal volunteer & 21 & $\mathbf{F}$ & 194 & 47 & 214 & 42 \\
\hline & Normal volunteer & 20 & $\mathbf{M}$ & 141 & 39 & 187 & 73 \\
\hline & $\begin{array}{l}\text { Familial hyper- } \\
\text { cholesterolemia }\end{array}$ & 22 & $\mathbf{M}$ & 290 & 76 & & 132 \\
\hline \multirow[t]{2}{*}{6} & Essential hyper- & 22 & 1Ve & 290 & 10 & 500 & 132 \\
\hline & cholesterolemia & 27 & $\mathrm{~F}$ & 355 & 94 & 261 & 78 \\
\hline \multirow{3}{*}{$\begin{array}{l}7 \\
8\end{array}$} & Normal volunteer & 28 & $\mathbf{M}$ & 106 & 27 & 147 & 98 \\
\hline & $\begin{array}{l}\text { Essential hyper- } \\
\text { cholesterolemia, }\end{array}$ & & & & & & \\
\hline & $\begin{array}{l}\text { carbohydrate- } \\
\text { induced hyper- } \\
\text { lipemiat }\end{array}$ & 33 & $\mathbf{M}$ & 263 & 81 & 258 & 254 \\
\hline 9 & Normal volunteer & 61 & $\mathbf{F}$ & 220 & 46 & 201 & 69 \\
\hline 10 & Normal volunteer & 20 & $\mathbf{M}$ & 143 & 31 & 137 & 123 \\
\hline 11 & Normal volunteer & 20 & $\mathbf{M}$ & 145 & 39 & 201 & 171 \\
\hline
\end{tabular}

* TC $=$ total cholesterol, $\mathrm{FC}=$ free cholesterol, $\mathrm{PL}=$ phospholipid, and $\mathrm{TG}=$ triglyceride.

† On a 5-g fat diet this patient's triglyceride level rose to $466 \mathrm{mg}$ per $100 \mathrm{ml}$; on coconut oil formula $(60 \%$ fat, $15 \%$ protein, $25 \%$ carbohydrate), it fell to $194 \mathrm{mg}$ per $100 \mathrm{ml}$.

travenous preparation of cholecystokinin 1 was an in- rapid flow of clear golden-yellow concentrated bile. valuable aid. Often there was little or no bile return un- Aside from a flushing sensation coincident with the intil the cholecystokinin was given, whereupon there was a jection, there were no untoward reactions to cholecysto-

1 We are indebted to Dr. V. Mutt and Prof. E. Jorpes, Stockholm; for the supplies of cholecystokinin used. kinin.

Analysis of bile. A part of the bile sample was used for quantitative paper chromatography according to the

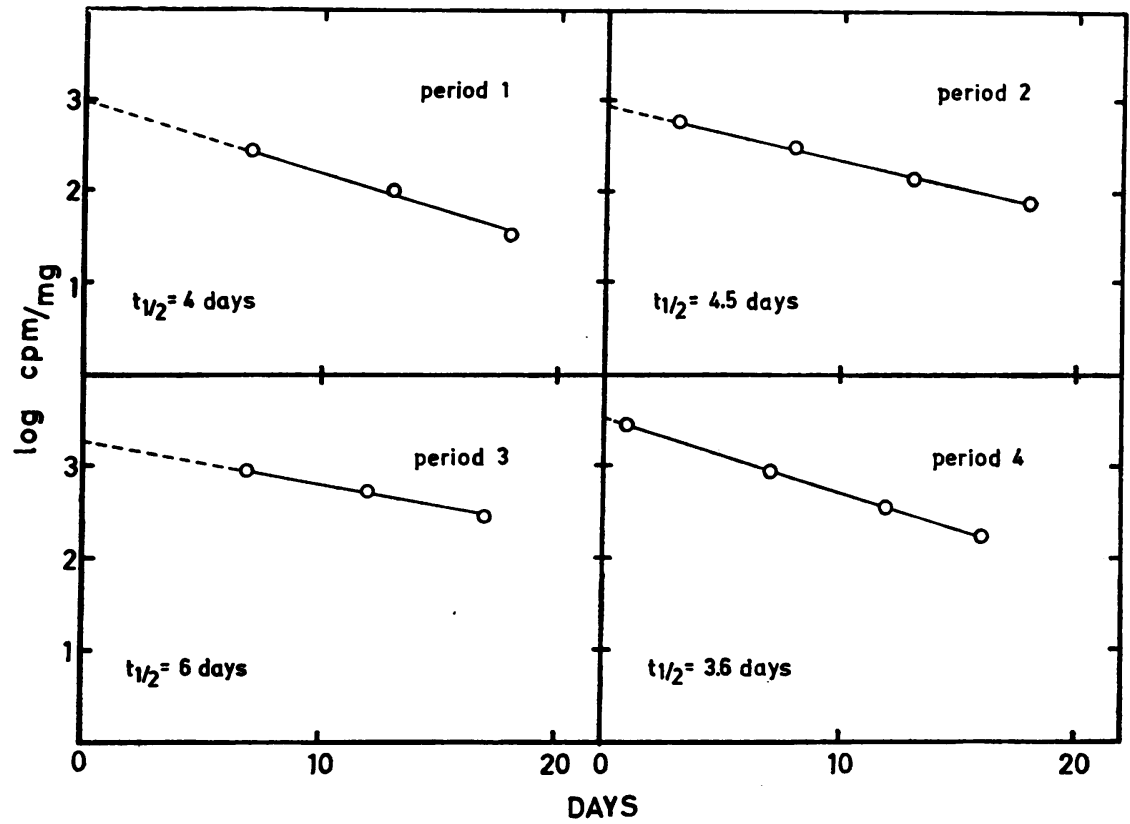

Fig. 1. Representative data (in Subject 5) to Show the linear fall in the LOGARITHM OF BILIARY CHOLIC ACID SPECIFIC RADIOACTIVITY AS A FUNCTION OF TIME. The four periods shown correspond to the four successive dietary test periods summarized in Figure 3. 
TABLE II

Half-life, pool size, and turnover of cholic acid in subjects on formula diets containing either corn oil or coconut oil*

\begin{tabular}{|c|c|c|c|c|c|}
\hline Subject & Dietary fat & $\begin{array}{l}\text { Cholic } \\
\text { acid } \\
\text { pool }\end{array}$ & $\begin{array}{l}\text { Half- } \\
\text { life of } \\
\text { cholic } \\
\text { acid }\end{array}$ & $\begin{array}{l}\text { Turn- } \\
\text { over of } \\
\text { cholic } \\
\text { acid }\end{array}$ & $\begin{array}{l}\text { Serum } \\
\text { choles- } \\
\text { terol }\end{array}$ \\
\hline & & $g$ & days & $g / d a y$ & $\begin{array}{c}\mathrm{mg} / \\
100 \mathrm{ml}\end{array}$ \\
\hline 5 & $\begin{array}{l}\text { Corn oil } \\
\text { Coconut oil } \\
\text { Corn oil }\end{array}$ & $\begin{array}{l}1.59 \\
0.75 \\
0.90\end{array}$ & $\begin{array}{l}4.5 \\
6.0 \\
3.6\end{array}$ & $\begin{array}{l}0.24 \\
0.08 \\
0.18\end{array}$ & $\begin{array}{l}190 \\
264 \\
171\end{array}$ \\
\hline 6 & Corn oil & 0.35 & 3.0 & 0.08 & 265 \\
\hline 7 & Coconut oil & 1.64 & 10.0 & 0.11 & 122 \\
\hline 8 & Coconut oil & 1.37 & 4.3 & 0.22 & 264 \\
\hline 10 & $\begin{array}{l}\text { Corn oil } \\
\text { Coconut oil }\end{array}$ & $\begin{array}{l}0.71 \\
1.00\end{array}$ & $\begin{array}{l}3.5 \\
6.5\end{array}$ & $\begin{array}{l}0.14 \\
0.11\end{array}$ & $\begin{array}{l}129 \\
198\end{array}$ \\
\hline 11 & $\begin{array}{l}\text { Corn oil } \\
\text { Coconut oil }\end{array}$ & $\begin{array}{l}1.00 \\
1.00\end{array}$ & $\begin{array}{l}1.7 \\
2.7\end{array}$ & $\begin{array}{l}0.41 \\
0.26\end{array}$ & $\begin{array}{l}103 \\
159\end{array}$ \\
\hline
\end{tabular}

* The formula diet supplied $60 \%$ of calorie intake in the form of fat (carbohydrate, $23.4 \%$; protein, $16.6 \%$ ).

Mean of serum cholesterol levels determined over the interval during

technique of Sjövall (22). The glycine conjugates were separated with the use of phase system $G_{D}$ [moving phase: ethylene chloride-heptane, 50:50 ( $\mathrm{vol} / \mathrm{vol})$; stationary phase: $70 \%$ aqueous acetic acid]. The taurine conjugates were separated with phase system $\mathrm{T}_{\mathbf{\Delta}}$ [moving phase: isoamyl acetate-heptane, 85:15 ( $\mathrm{vol} / \mathrm{vol})$; stationary phase: $70 \%$ aqueous formic acid]. The spots corresponding to the respective acids were eluted and the amounts determined colorimetrically from absorption spectra in $65 \%$ sulfuric acid (23). Each bile sample was analyzed in duplicate. The remainder of the bile was added to $200 \mathrm{ml}$ of $95 \%$ ethanol. The precipitated proteins were filtered off, the filtrate was evaporated to dryness, and the residue was saponified under pressure in $2 \mathrm{~N}$ sodium hydroxide for 12 hours at $120^{\circ} \mathrm{C}$. The saponified sample was acidified, and bile acids were extracted by shaking three times with equal volumes of ethyl ether. The solvent was removed in vacuo and the residue fractionated by reversed phase column chromatography $(24,25)$ with phase system $C_{1}(26)$ (moving phase: methanol-water, $1: 1$; stationary phase: chloroform-isooctanol, 1:1). The fractions containing cholic acid were combined and acidified with hydrochloric acid, and the cholic acid was extracted with ethyl ether. It was then recrystallized from ethyl acetate after evaporation of the ether.

The $\mathrm{C}^{14}$ content of the crystalline cholic acid was determined after combustion of a sample weighing 2 to 10 $\mathrm{mg}$ by the gas-phase counting method of Glascock (27).

\section{Results}

Bile acid pool and turnover of cholic acid. Figure 1 shows representative semilogarithmic plots of the specific activity of cholic acid as a function of time during four diet periods in a single subject (No. 5). True first-order decay curves like these were obtained in all of the subjects studied. The dilution of the administered dose and, consequently, the size of the miscible pool of cholic acid, was calculated by extrapolation of the specific activity time curve to zero time. The turnover of cholic acid was calculated from the relation, $\mathrm{P}=$ $\mathrm{k} \cdot \mathrm{A}$, where $\mathrm{k}=$ rate constant $=0.693 / \mathrm{t}_{\frac{1}{2}}, \mathrm{P}=$ turnover (daily production) in grams per day, $A=$ pool size in grams, and $t_{\frac{1}{2}}=$ half-life in days.

Tables II and III show the values for the size of the cholic acid pool and the concentration of serum cholesterol during the turnover studies in the 11 subjects.

Figures 2, 3, and 4 show the changes in serum cholesterol concentration and in cholic acid turnover in individual subjects in relation to the points at which dietary regimens were changed. In the bar graphs are shown the mean percentages of glycocholic, glycochenodeoxycholic, and glycodeoxycholic acids found in duodenal bile on each dietary regimen.

The range of values found for the half-life of cholic acid in subjects on corn oil liquid-formula

TABLE III

Half-life, pool size, and turnover of cholic acid in subjects on solid diets

\begin{tabular}{|c|c|c|c|c|c|}
\hline Subject & Diet & $\begin{array}{c}\text { Cholic } \\
\text { acid } \\
\text { pool }\end{array}$ & $\begin{array}{l}\text { Half- } \\
\text { life of } \\
\text { cholic } \\
\text { acid }\end{array}$ & $\begin{array}{l}\text { Turn- } \\
\text { over of } \\
\text { cholic } \\
\text { acid }\end{array}$ & $\begin{array}{l}\text { Serum } \\
\text { choles- } \\
\text { 'terol* }\end{array}$ \\
\hline \multirow{3}{*}{$1 \dagger$} & \multirow{3}{*}{$\begin{array}{l}\text { 5-g fat diet }+ \\
\text { corn oil }(35 \%) \ddagger \\
\text { 5-g fat diet }+ \\
\text { coconut oil }(35 \%)\end{array}$} & $g$ & days & $g / d a y$ & $\begin{array}{c}\mathrm{mg} / \\
100 \mathrm{ml}\end{array}$ \\
\hline & & 0.83 & 4.5 & 0.13 & 116 \\
\hline & & 0.99 & 4.5 & 0.15 & 145 \\
\hline \multirow[t]{2}{*}{$2 \dagger$} & \multirow{2}{*}{$\begin{array}{l}5-\mathrm{g} \text { fat diet }+ \\
\text { corn oil }(35 \%) \\
5-\mathrm{g} \text { fat diet }+ \\
\text { coconut oil }(35 \%)\end{array}$} & 1.76 & 5.9 & 0.21 & 96 \\
\hline & & 0.83 & 5.0 & 0.12 & 132 \\
\hline \multirow[t]{2}{*}{$3 \dagger$} & \multirow{2}{*}{$\begin{array}{l}\text { 5-g fat diet }+ \\
\text { corn oil }(35 \%) \\
\text { 5-g fat diet }+ \\
\text { coconut oil }(35 \%)\end{array}$} & 1.45 & 5.0 & 0.20 & 121 \\
\hline & & 0.53 & 3.5 & 0.11 & 207 \\
\hline $4 \dagger$ & $\begin{array}{l}\text { 5-g fat diet }+ \\
\text { corn oil }(35 \%) \\
5-\mathrm{g} \text { fat diet }+ \\
\text { coconut oil }(35 \%)\end{array}$ & $\begin{array}{l}0.93 \\
0.74\end{array}$ & $\begin{array}{l}2.7 \\
2.5\end{array}$ & $\begin{array}{l}0.24 \\
0.21\end{array}$ & $\begin{array}{r}96 \\
135\end{array}$ \\
\hline 5 & House diet $(35 \%)$ & 1.19 & 3.0 & 0.28 & 310 \\
\hline $6 \dagger$ & $\begin{array}{l}\text { 5-g fat diet }+ \\
\text { corn oil }(35 \%)\end{array}$ & 0.67 & 3.3 & 0.14 & 251 \\
\hline 7 & House diet $(40 \%)$ & 1.24 & 5.0 & 0.18 & 93 \\
\hline 8 & 5-g fat diet & 1.04 & 6.5 & 0.11 & 196 \\
\hline 9 & House diet & 0.43 & 3.3 & 0.09 & 215 \\
\hline
\end{tabular}

* Mean of serum cholesterol levels determined over the interval dur-

ing which cholic acid turnover was measured. $\mathrm{T}$ The basic diet contained $5 \mathrm{~g}$ fat and was supplemented with
corn oil or coconut oil to give a total of $35 \%$ of the calories as fat. t Figures in parentheses indicate percentage of total calories provided as fat. 


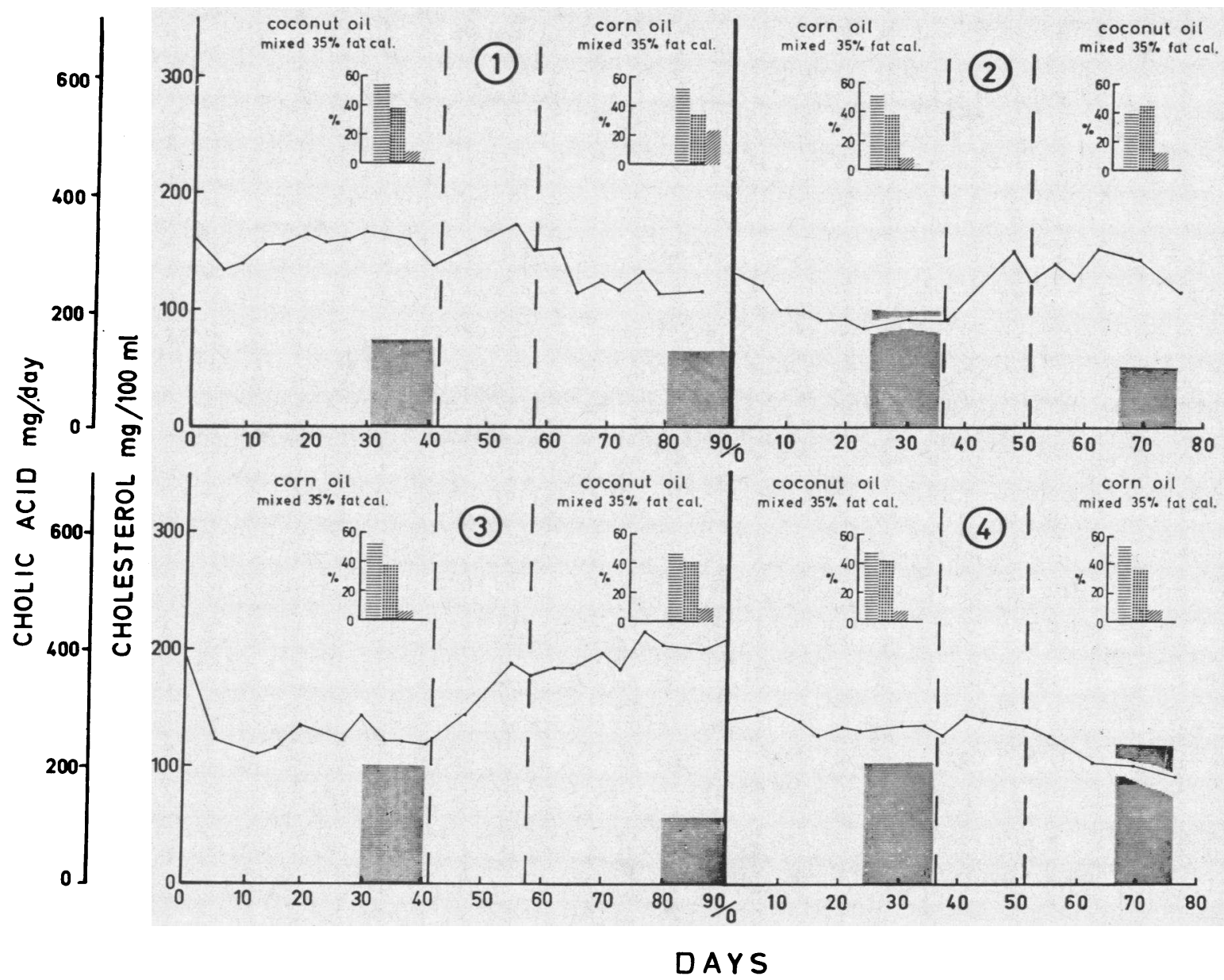

Fig. 2. Serum cholesterol level, cholic acid turnover, and bile acid composition of duodenal bile in SubJECTS 1 TO 4 AS INFLUENCED BY COCONUT OIL AND CORN OIL SUPPLEMENTS (35\% OF CALORIES) TO A BASIC 5-G FAT DIET. The height of the large cross-hatched bars at the bottom of each graph indicates the rate of cholic acid turnover, in milligrams per day, calculated from serial measurements of cholic acid-24- ${ }^{14} \mathrm{C}$ specific radioactivity in duodenal bile samples (see Methods). The width of the bar indicates the time period over which duodenal bile samples were collected and analyzed for determination of turnover. The upper bar graphs inset into each chart show the relative contributions of glycocholic acid (horizontal lines), glycochenodeoxycholic acid (dots), and glycodeoxycholic acid (diagonal lines) to the total of the three in the glycine conjugates of duodenal bile taken during the course of the cholic acid turnover study.

diets was from 1.7 to 4.5 days, with a mean of 3.3 days (Table II). Subjects on coconut oil formula showed half-life values from 2.7 to 10 days with a mean of 5.9 days. For subjects on solid diets, the half-life found during corn oil supplementation ( $35 \%$ of calories) varied from 2.7 to 5.9 days (mean 4.3), during coconut oil supplementation from 2.5 to 5.0 days (mean 3.9) (Table III).

The nature of the dietary fat, whether in liquid formula or fed as a supplement, did not systematically alter the size of the cholic acid pool. The calculated turnover for cholic acid on corn oil formula diets ranged from 0.08 to $0.41 \mathrm{~g}$ per day (mean 0.21 ), on coconut oil formula from 0.11 to $0.26 \mathrm{~g}$ per day (mean 0.16 ). On solid diets supplemented with corn oil, turnover ranged from 0.13 to $0.24 \mathrm{~g}$ per day (mean 0.18 ), supplemented with coconut oil, from 0.11 to $0.21 \mathrm{~g}$ per day (mean 0.15).

Direct comparison of the two oils in the same individual was made in four subjects on oil-supplemented solid diets (Subjects 1 to 4, Table III and Figure 2). As expected, all subjects showed a lower serum cholesterol level during the corn oil 
period. In Subjects 2 and 3, cholic acid turnover was definitely higher on corn oil, but in Subjects 1 and 4 the difference was small and probably not significant. The increase in turnover on corn oil in Subjects 2 and 3 was associated with a much larger cholic acid pool size. A similar direct comparison on liquid formula diets was made in three cases (Subjects 5, 10, and 11, Table II and Figures 3 and 4). In Subject 5, a third period returning to corn oil was added. The cholic acid turnover was greater during the corn oil period in Subjects 5 and 11, but the difference in Subject 10 was of marginal significance. However, the response of serum cholesterol in Subject 10 was as great as the response in Subject 11.

In four additional experiments, transitions between solid and liquid diets in various combinations were studied. In two of these there was a marked change in level of serum cholesterol (Subjects 5 and 8). In Subject 5, serum cholesterol fell from 310 to $190 \mathrm{mg}$ per $100 \mathrm{ml}$ on transition from a regular diet (35\% of calories from fat) to a corn oil formula diet, yet cholic acid turnover decreased from 0.28 to $0.24 \mathrm{~g}$ per day. In Subject 8 , transition from a 5-g fat diet to a coconut oil formula diet ( $60 \%$ of calories as fat) was accompanied by a rise in serum cholesterol level from 196 to $264 \mathrm{mg}$ per $100 \mathrm{ml}$, yet cholic acid turnover increased from 0.11 to $0.22 \mathrm{~g}$ per day. In Subject 6, transition from a corn oil formula diet ( $60 \%$ of calories as fat) to a corn oil-supplemented diet (35\% of calories as fat) caused very little change in serum cholesterol (265 to $251 \mathrm{mg}$ per $100 \mathrm{ml}$ ), but cholic acid turnover increased from 0.08 to $0.14 \mathrm{~g}$ per day. Finally, in Subject 7 , transition from the standard hospital diet ( $40 \%$ of calories from fat) to a coconut oil formula diet increased serum cholesterol level from 93 to $122 \mathrm{mg}$ per $100 \mathrm{ml}$, whereas cholic acid turnover decreased from 0.18 to $0.11 \mathrm{~g}$ per day.

Bile acids in duodenal bile samples. In most subjects, bile samples from two different intubations, usually the first and third, were analyzed in detail for composition (Tables IV and V). Usually only minor differences were noted between the two samples, but in some cases a more ap-

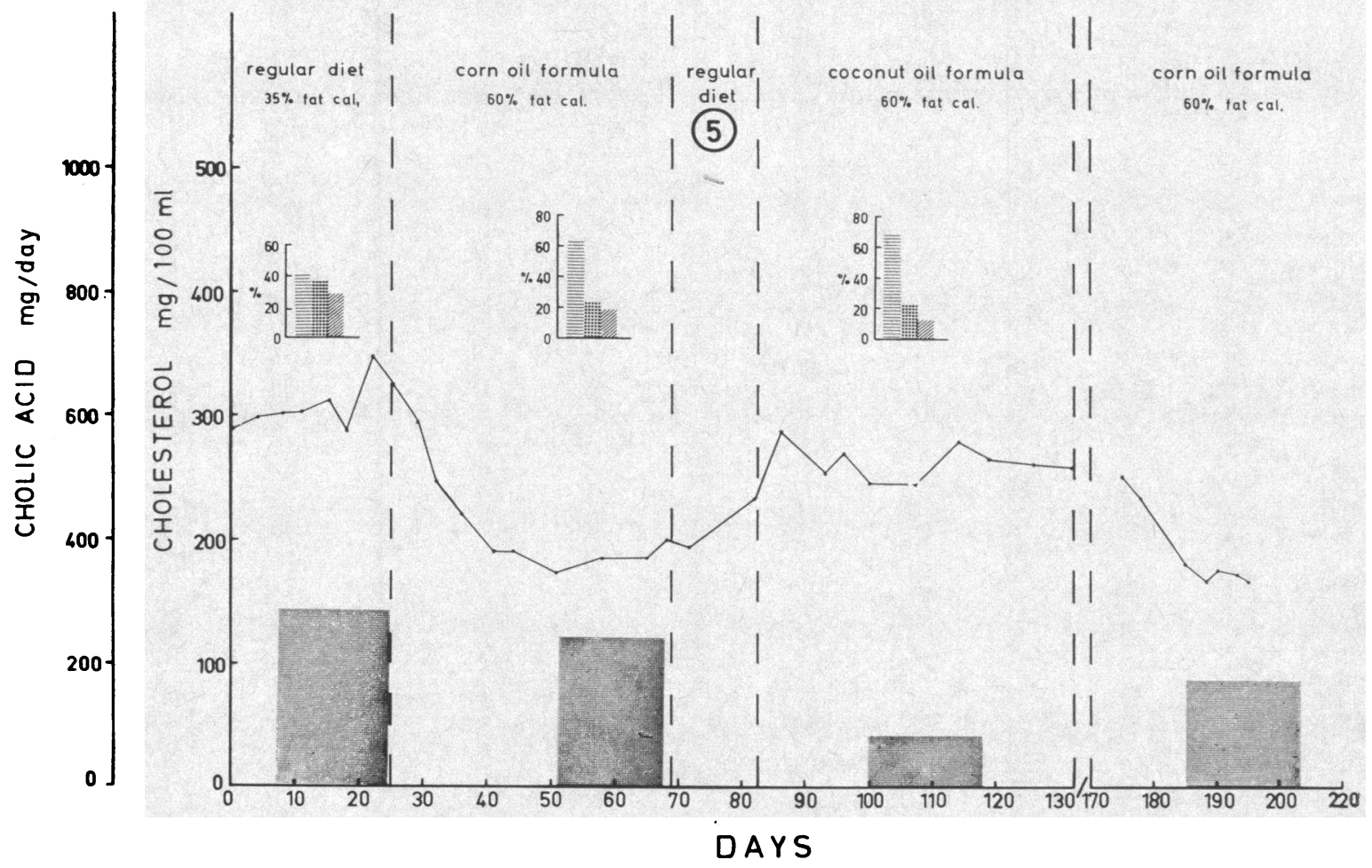

Fig. 3. Serum cholesterol level, cholic acid turnover, and bile acid composition of duodenal bile in SubJeCt 5 Through Four Dietary test PERIoDs. Symbols as in the legend for Figure 2. Bile acid composition data were not obtained in the fourth test period. 


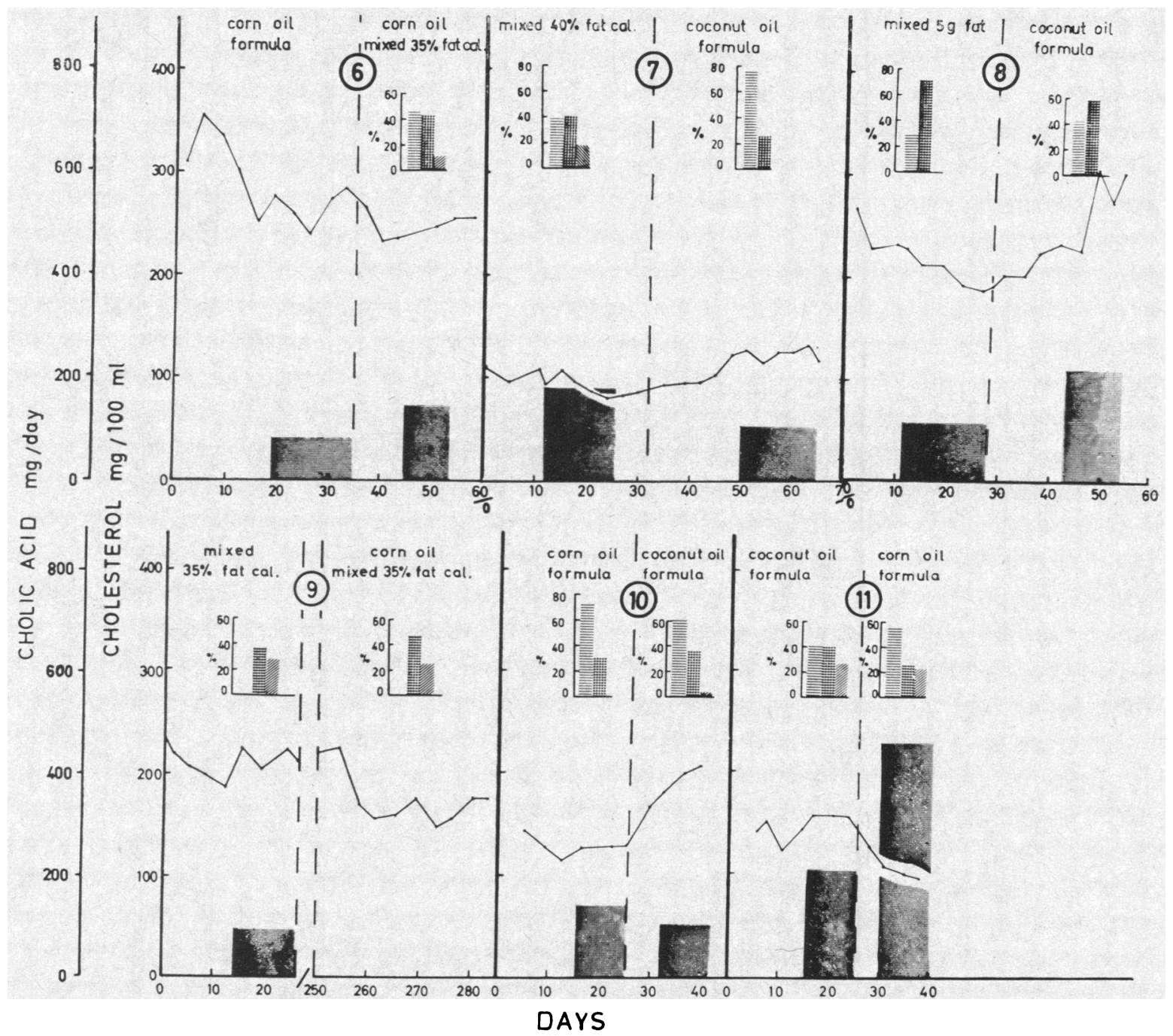

Fig. 4. Serum cholesterol level, cholic acid turnover, and bile acid composition of duodenal bile in SubJECTS 6 to 11. Symbols as in the legend for Figure 2. Bile acid composition data for the first test period in Subject 6 and cholic acid turnover in the second test period in Subject 9 were not obtained.

preciable variation in composition was found ( $\mathrm{Sub}-$ jects 7 and 11).

Conjugation. In general, the ratio between glycine-conjugated and taurine-conjugated bile acids ( $G: T$ ) was higher on the solid diets than on the liquid formula diets. This difference is also seen when direct comparison is made of solid and liquid diets containing the same fat (Tables IV and V). For coconut oil-containing diets, the mean ratios were 2.3 versus 1.1 , and for corn oil-containing diets, 2.6 versus 2.2 , for solid and liquid diets, respectively. The effect is clearly seen in those subjects $(5,7$, and 8$)$ that were studied on both a solid diet and on a formula diet. Tables IV and V also show that the average ratio of glycine- to taurine-conjugated bile acids was higher in subjects receiving corn oil than in those receiving coconut oil ; on liquid formula diets, the mean ratios were 2.2 versus 1.1 , and on solid diets 2.6 versus 2.3.

Relative concentrations of the principal bile acids. The relative amounts of the three principal bile acids in bile-cholic acid, chenodeoxycholic acid, and deoxycholic acid-were determined by analysis of their glycine conjugates, since analysis of the taurine conjugates of the three individual 
TABLE IV

Ratio of glycine-conjugated to taurine-conjugated bile acids $(G: T)$ and ratio between glycocholic $(G C)$, glycochenodeoxycholic (GCD), and glycodeoxycholic (GD) acids in duodenal bile of subjects on formula diets*

\begin{tabular}{|c|c|c|c|c|}
\hline \multirow[b]{3}{*}{ Subject } & \multicolumn{2}{|c|}{ G:T } & & \\
\hline & \multirow{2}{*}{$\begin{array}{l}\text { Coco- } \\
\text { nut } \\
\text { oil }\end{array}$} & \multirow{2}{*}{$\underset{\text { oil }}{\text { Corn }}$} & \multicolumn{2}{|c|}{ GC:GCD:GD } \\
\hline & & & Coconut oil & Corn oil \\
\hline 5 & 1.0 & 1.8 & $4.1: 1: 0.8$ & $3.1: 1: 1.1$ \\
\hline 7 & 1.5 & 1.3 & $2.6: 1: 0.4$ & $2.9: 1: 0.6$ \\
\hline & & & $3.5: 1: 0.0$ & \\
\hline 8 & 0.5 & & $0.7: 1: 0.0$ & \\
\hline 10 & 1.2 & 1.3 & $2.0: 1=0.2$ & $2.8: 1: 0.0$ \\
\hline & 0.9 & 1.3 & $1.3: 1: 0.0$ & $2.5: 1: 0.0$ \\
\hline 11 & $\begin{array}{l}1.3 \\
1.8\end{array}$ & $\begin{array}{l}2.9 \\
3.8\end{array}$ & $\begin{array}{l}1.0: 1: 0.7 \\
1.0: 1: 0.6\end{array}$ & $\begin{array}{l}3.4: 1: 0.9 \\
1.6: 1: 0.9\end{array}$ \\
\hline Mean & 1.1 & 2.2 & & \\
\hline
\end{tabular}

* Analyses were done on two bile samples obtained at two differen times during each dietary period.

acids is technically difficult. Previous work has shown, however, that there is no significant difference in the composition of the glycine and taurine conjugates (15). Tables IV and $\mathrm{V}$ give the concentrations of glycocholic acid (GC) and of glycodeoxycholic acid (GD) in relation to that of glycochenodeoxycholic acid (GCD) set arbitrarily equal to 1.0. Values are given for bile samples collected on two different occasions in the same diet period. Subjects 5,7 , and 8 , studied on both a solid and a liquid diet, had a lower relative concentration of glycochenodeoxycholic acid on the formula diet. In Subject 5 (Figure 3), the relative concentration of glycochenodeoxycholic acid (relative to that of glycocholic and glycodeoxycholic acids) decreased on liquid formula diet to about the same extent whether coconut oil or corn oil was used. For both Subjects 7 and 8, similar results were obtained on changing from a standard hospital diet ( $40 \%$ of calories from fat) or from a 5-g fat diet, respectively, to a coconut oil liquid formula ( $60 \%$ of calories from fat). When the dietary fat was saturated, the relative concentration of chenodeoxycholic acid tended to be higher. Thus on the liquid diet, chenodeoxycholic acid accounted for $36 \%$ of the total bile acids when coconut oil was given, but for only $25 \%$ when corn oil was given. On the solid diets, the corresponding figures were $42 \%$ and $38 \%$, respectively.

There were large differences in deoxycholate:

TABLE V

Ratio of glycine-conjugated to taurine-conjugated bile acids $(G: T)$ and ratio between glycocholic (GC), glycochenodeoxycholic $(G C D)$, and glycodeoxycholic acids $(G D)$ in duodenal bile from subjects on solid diets*

\begin{tabular}{|c|c|c|c|c|c|}
\hline \multirow[b]{2}{*}{ Subject } & \multirow[b]{2}{*}{ Nature of diet } & \multicolumn{2}{|c|}{ G:T } & \multicolumn{2}{|c|}{ GC:GCD:GD } \\
\hline & & Coconut oil & Corn oil & Coconut oil & Corn oil \\
\hline 1 & $\begin{array}{l}5-g \text { fat diet }+ \text { oil } \\
\text { supplement } \\
(35 \%) t\end{array}$ & $\begin{array}{l}2.9 \\
3.5\end{array}$ & $\begin{array}{l}3.2 \\
3.4\end{array}$ & $\begin{array}{l}1.6: 1: 0.2 \\
1.3: 1: 0.3\end{array}$ & $\begin{array}{l}1.5: 1: 0.4 \\
1.6: 1: 0.4\end{array}$ \\
\hline 2 & $\begin{array}{l}\text { 5-g fat diet }+ \text { oil } \\
\text { supplement } \\
(35 \%)\end{array}$ & $\begin{array}{l}1.3 \\
2.0\end{array}$ & $\begin{array}{l}2.7 \\
2.4\end{array}$ & $\begin{array}{l}0.9: 1: 0.3 \\
0.8: 1: 0.3\end{array}$ & $\begin{array}{l}1.5: 1: 0.2 \\
1.2: 1: 0.3\end{array}$ \\
\hline 3 & $\begin{array}{l}\text { 5-g fat diet }+ \text { oil } \\
\text { supplement } \\
(35 \%)\end{array}$ & 1.1 & $\begin{array}{l}1.5 \\
1.7\end{array}$ & $\begin{array}{l}1.0: 1: 0.2 \\
1.2: 1: 0.3\end{array}$ & $\begin{array}{l}1.3: 1: 0.3 \\
1.5: 1: 0.1\end{array}$ \\
\hline 4 & $\begin{array}{l}\text { 5-g fat diet }+ \text { oil } \\
\text { supplement } \\
(35 \%)\end{array}$ & 2.9 & 3.5 & $1.2: 1: 0.3$ & $1.6: 1: 0.2$ \\
\hline 5 & House diet $(35 \%)$ & \multicolumn{2}{|c|}{$\begin{array}{l}5.7 \\
5.7\end{array}$} & \multicolumn{2}{|c|}{$1.2: 1: 1.0$} \\
\hline 6 & $\begin{array}{l}5 \text {-g fat diet }+ \text { oil } \\
\text { supplement } \\
(35 \%)\end{array}$ & & 2.5 & & $\begin{array}{l}1.0: 1: 0.3 \\
1.1: 1: 0.3\end{array}$ \\
\hline 7 & House diet $(40 \%)$ & \multirow{2}{*}{\multicolumn{2}{|c|}{$\begin{array}{l}3.1 \\
1.8 \\
1.1 \\
0.8\end{array}$}} & \multirow{2}{*}{\multicolumn{2}{|c|}{$\begin{array}{l}1.0: 1: 0.4 \\
1.2: 1: 0.6 \\
0.4: 1: 0.0 \\
0.4: 1: 0.0\end{array}$}} \\
\hline 8 & 5-g fat diet & & & & \\
\hline 9 & $\begin{array}{l}\text { House diet }(35 \%) \\
5 \text {-g fat diet }+ \text { oil } \\
\text { supplement } \\
(35 \%)\end{array}$ & \multicolumn{2}{|c|}{1.1} & \multicolumn{2}{|c|}{$1.2: 1: 0.8$} \\
\hline
\end{tabular}

* Analyses were done on two bile samples obtained at two different times during each dietary period (except in Subject 9).

$\dagger$ Figures in parentheses indicate the percentage of calories provided as fat. 
cholate ratios in different subjects on identical diets. In the studies in which the same subject was given corn oil and coconut oil in otherwise identical diets, the nature of the dietary fat had no consistent effect on deoxycholate: cholate ratios. In three subjects, transition from solid diet to liquid diet was studied. In Subject 5 , the ratio fell from 0.84 to 0.24 ; in Subject 7, from 0.55 to 0.0. In Subject 8, there was no deoxycholate detected on either diet. This was the only subject on a solid diet whose bile contained no deoxycholate, and he was the only subject on a $5-\mathrm{g}$ fat diet without supplement. In three of the five subjects on liquid formula diets, the bile contained no detectable deoxycholate.

\section{Discussion}

In all of these studies, the semilogarithmic plot of cholic acid specific radioactivity against time remained linear over the 8- to 15-day period between the initial and the final sampling of bile. This can be taken as strong evidence that the subjects were in a steady state with regard to cholic acid turnover at the time turnover studies were begun in each diet period. If there were a net loss from the cholic acid pool and, simultaneously, an exactly proportional decrease in formation of new unlabeled cholic acid, this would have gone undetected. Such a balanced parallel shift between successive sampling times seems unlikely. In most studies, the subject had been on a given test diet for over 2 weeks before turnover measurements were started (average, 19 days). Turnover studies during the second test diet in the cases of Subjects 10 and 11 were started before serum cholesterol levels had stabilized, but the final points were obtained 14 days after the change in diet. However, in these subjects, too, the decline in specific radioactivity followed first-order kinetics. Thus, it can be seen that the data reported relate to what was apparently a steady-state cholic acid turnover in each diet period. No attempt was made to study the period of transition from one diet to another, during which time, of course, the mathematical analysis used here would be inapplicable.

The mean value and range of values for the size of the miscible body pool of cholic acid found in the present study were comparable to those previously found by the same methods $(17,28)$. The pool size was not affected consistently either by changing from solid to liquid diets or by substituting coconut oil for corn oil. The half-life of cholic acid was in the same range as in the earlier studies, except that in the group of subjects on a liquid diet containing coconut oil, the mean (5.9 days) was higher than that previously encountered.

The turnover of cholic acid on solid diets supplemented with corn oil was higher than on coconut oil-supplemented diets in two subjects, but not significantly different in the other two. In the three subjects studied both on corn oil and on coconut oil contained in liquid formula diets, the turnover was clearly greater during the corn oil period in two, but marginally different in the third. If all seven subjects, in whom direct comparisons of saturated and unsaturated fats were made, are considered together and the results are analyzed as paired data, a small but significant difference is found. Cholic acid turnover was higher by $0.07 \mathrm{~g}$ per day on the unsaturated fat. With regard to the question of whether the changes in cholic acid output are related to the changes in serum cholesterol, the results in the two first diet periods for Subject 5 and the results in Subject 8 are particularly relevant. In both cases, a dietary change accompanied by large changes in serum cholesterol level was associated with parallel rather than inverse changes in cholic acid output.

If all nine studies in which dietary fat transitions were made and cholic acid output data were obtained are grouped together, there is no significant correlation between changes in serum cholesterol value and changes in cholic acid output. Such a lack of correlation has also been noted in several other similar studies. Hellström and Lindstedt (29) found that cholic acid turnover was no different on solid diets supplemented on the one hand with butterfat or on the other hand with corn oil ( $40 \%$ of calories), even though there were highly significant differences in plasma cholesterol levels. Avigan and Steinberg (13, 30 ), using a ${ }^{14} \mathrm{C}$ balance method similar to that described by Hellman, Rosenfeld, Insull, and Ahrens $(11,12)$, found no consistent relation between the effects of unsaturated fat (corn oil or safflower oil) or saturated fat (coconut oil) on serum cholesterol level and on total bile acid or sterol excretion. Spritz, Ahrens, and Grundy have used a battery of isolation procedures that permit quantification of 
total bile acids and sterols in human feces. They found no significant difference in end-product excretion when cholesterol-free liquid formula diets containing saturated and unsaturated fats $(40 \%$ of calories), with and without vegetable sterols, were alternated $(8,10)$. Thus, in four independent studies, utilizing isotopic methods in some cases and direct analytical methods in others, there has been no correlation between diet-induced changes in plasma cholesterol levels and changes in bile acid output; in two studies in which total sterol output was determined either isotopically or analytically, there was again no correlation between diet-induced changes in plasma sterol levels and changes in fecal sterol output.

Any explanation of changes of serum cholesterol level must ultimately be related to changes either in the rate of production of new lipoproteins, the rate of their removal from the blood, or a combination of the two. Although such changes may be initiated by and be secondary to changes in hepatic metabolism of sterols and bile acids, other explanations are equally possible. For example, the fatty acid composition of the diet might influence the rate of formation of new lipoproteins or their rate of secretion into the plasma or both. If this occurred, there might well be consequent changes in the fecal excretion of sterols and bile acids, but as a secondary phenomenon. In other words, there is no reason a priori to assume that the nature of the dietary fat must have a primary action on enzyme systems directly involved in sterol or bile acid metabolism. From the present studies, nothing can be said concerning which components of the natural oils fed are responsible for either the changes in plasma cholesterol levels or the changes in bile acid patterns or turnover.

Our studies show that the ratio of glycine- to taurine-conjugated bile acids in duodenal bile is influenced both by the form of the diet (solid or liquid) and by the nature of the dietary fat (coconut oil versus corn oil). The values obtained in the subjects studied on a solid diet were close to those found previously in healthy young subjects on regular diets (31) (corn oil, 2.6 and coconut oil, 2.3 in the present study, compared to 3.2 in the previous study). The ratio was consistently lower in the present series of subjects studied on liquid formula diets (corn oil, 2.2; coconut oil, 1.1). There was in four cases a marked increase in the ratio on changing from coconut oil to corn oil ; in the other three the increase was smaller but probably significant. The mechanism underlying these changes is not clear. Several factors are known to influence the relative abundance of glycine and taurine conjugates. For example, feeding large amounts of taurine can lead to a twofold increase in taurine conjugates; on the other hand, large increases in glycine intake do not change the proportion of two types of conjugates (32). In hypothyroid patients, a relative increase in the glycine conjugates has been found (33). Impairment of liver function leads to a diminished capacity of the liver to conjugate bile acids with glycine in vitro (34). Thus, changes in the glycine: taurine ratio can be effected either by changes in the available amounts of taurine or its precursors, or by changes in the activity of the conjugating systems in the liver. Of course, it is also possible that alterations in bacterial flora could lead to differences. For example, changes in the rates of hydrolysis of the different conjugates or in the rates of their reabsorption would result in changes in the ratios observed in bile.

The cholic: chenodeoxycholic: deoxycholic ratios found in the present study for subjects on solid diets were very similar to those previously reported in young subjects on ad libitum diets $(1.1: 1.0: 0.6)(31)$. In the three studies for which direct comparison is available, the relative amount of chenodeoxycholic acid decreased in every instance when a liquid formula diet was substituted for a solid diet. Most of the subjects on liquid formula diets had a lower relative chenodeoxycholic acid concentration than the subjects on a solid diet, independent of the type of oil used in the formula diet. The changes in the cholic: chenodeoxycholic acid ratio induced by substituting saturated for unsaturated fat were less striking. In most instances, however, there was a relative increase in chenodeoxycholic acid when coconut oil was used.

The factors that regulate the proportions in which cholic and chenodeoxycholic acid are formed in liver from cholesterol are not understood. Both in animal and in human studies, it has been shown that thyroid hormone causes a relative increase in the concentration of chenodeoxycholic acid (28, 35-37). The fact that this effect has been demonstrated in rats with bile fistulas $(35,37)$. indicates 
that the cholic to chenodeoxycholic acid ratio is affected by the bile acid synthesizing system in the liver. On the other hand, there is also evidence that chenodeoxycholic acid, like cholic acid, can be degraded by intestinal bacteria (38-40), and changes in such bacterial action could also lead to alterations in the cholic to chenodeoxycholic acid ratio.

Because of the large differences in cholate: deoxycholate ratios from subject to subject, even on identical diets, meaningful comparisons can only be made of values obtained in successive diet periods in individual subjects. The nature of the dietary fat did not have any consistent effect on this ratio. However, transition from a solid diet to a liquid diet was in two cases accompanied by a decrease in the ratio of deoxycholate to cholate. The third subject studied in this way showed no deoxycholate on either solid or liquid diet. The number of studies is too limited to warrant general conclusions, but it is of interest to note that three of five subjects studied on liquid formula diets showed no deoxycholate in bile, whereas only one of nine subjects on solid diets lacked deoxycholate. The latter (No. 8) was on a 5-g fat diet. The bile of subjects on ad libitum diets in Sjövall's series of 21 patients (31) and Hellström and Lindstedt's series of 13 subjects on fat-supplemented solid diets (29) always contained deoxycholate. Since deoxycholic acid is known to arise exclusively from preformed cholic acid as the result of bacterial action in the intestine $(41,42)$, changes in the deoxycholate: cholate ratio induced by changes in the diet must reflect a change in the nature or activity of the bacterial flora or else a change in the time of exposure of the bile acids to bacterial action (e.g., changes in intestinal motility).

No conclusions can be drawn from the present studies concerning the question of whether the fall in serum cholesterol level induced by unsaturated fat is accounted for by an increase in end-product excretion. First, only the turnover of cholic acid was measured. Although the output of deoxycholic acid is included in the calculated values for cholic acid output (since it is exclusively a product of cholic acid degradation), chenodeoxycholic acid has an independent metabolic fate. If it were assumed that chenodeoxycholic acid had the same half-life as cholic acid, the calculated total bile acid output on coconut oil would be raised relative to that on corn oil (since there was a relative increase in the concentration of chenodeoxycholic acid on coconut oil). However, it has been shown that, under some circumstances at least, chenodeoxycholic acid may have a half-life different from that of cholic acid (16). Second, no measurements of sterol balance were made, and a total net balance cannot be drawn. However, as pointed out above, in other studies in this laboratory $(13,30)$, and in the studies of Spritz, Ahrens, and Grundy $(8,10)$, no consistent changes in sterol balance have been noted with similar changes in diet. Finally, it should be pointed out that in reaching a new steady state, there need not be any "balance" between cholesterol disappearing from the plasma and end products excreted in the feces. Animal studies have shown, for example, that there can be important changes in the concentrations of cholesterol in certain organs accompanying changes in dietary fat (43-47). Also, there may be changes in the rate of cholesterol synthesis, which must be taken: into account in calculating balance. In rats, corn oil-rich diets do in fact enhance the rate of hepatic cholesterol synthesis $(44,48)$. It should be noted that in most of the experiments described here, the measurement of cholic acid turnover was made at a time when a new steady state had been reached, as discussed above. This therefore implies that in those subjects in whom there appeared to be a change in cholic acid turnover associated with a change in diet, the change was sustained for at least 2 to 3 weeks and possibly for as long as the intake of the same dietary fat continued. Previous studies with liquid formula diets like those used here have failed to demonstrate any consistent changes in fecal sterol output $(10,13)$. Therefore, when turnover appeared to change. it is quite possible that there may have been simultaneous and parallel changes in the rate of cholesterol synthesis.

Although we can draw no firm conclusions regarding the mechanism of action of dietary fat on sterol and bile acid metabolism, the present results suggest that more attention should be focused on the gastrointestinal tract. Changes in the pattern of bacterial flora or changes in gastrointestinal motility or both could contribute to changes in bile acid turnover and to changes in composition observed on transition from solid to liquid diets and on transition from one dietary fat to another. 
However, interactions at the enzymatic level are equally likely.

\section{Summary}

The ratio of glycine to taurine bile acid conjugates and the cholic: chenodeoxycholic: deoxycholic acid ratio in duodenal bile were determined in 11 subjects on various diets. The glycine: taurine ratio was lower on fat-rich liquid formula diets than on solid diets, both on corn oil and on coconut oil diets. The relative contribution of chenodeoxycholic acid to the mixture found in bile samples was lower on liquid formula diets than on solid diets. On corn oil, the relative concentration of chenodeoxycholic acid was generally lower than on coconut oil when the diets were otherwise identical. There were no consistent changes in the pool size of cholic acid, either with a transition from solid to liquid diet or with changes in the nature of dietary fat. In four subjects, the daily turnover of cholic acid was greater on corn oilcontaining diets than on coconut oil-containing diets that were otherwise identical. In three other subjects, however, there was little or no change in cholic acid output, even though the changes in serum cholesterol were comparable in magnitude to those effected in subjects showing a change in cholic acid turnover. In two additional subjects, transition from a solid diet to a formula diet was associated with large changes in serum cholesterol level with parallel rather than reciprocal changes in cholic acid turnover. The results as a whole, therefore, lend no support to the proposition that changes in serum cholesterol level brought about by manipulation of dietary fat intake are necessarily accompanied by reciprocal changes in cholic acid turnover.

\section{References}

1. Gordon, H., B. Lewis, L. Eales, and J. F. Brock. Dietary fat and cholesterol metabolism. Fæcal elimination of bile acids and other lipids. Lancet 1957, 2, 1299.

2. Haust, H. L., and J. M. R. Beveridge. Effect of varying type and quantity of dietary fat on the fecal excretion of bile acids in humans subsisting on formula diets. Arch. Biochem. 1958, 78, 367.

3. Goldsmith, G. A., J. G. Hamilton, and O. N. Miller. Lowering of serum lipid concentrations; mechanisms used by unsaturated fats, nicotinic acid, and neomycin : excretion of sterols and bile acids. Arch. intern. Med. 1960, 105, 512.
4. Roels, O. A., and S. A. Hashim. Influence of fatty acids on serum cholesterol. Fed. Proc. 1962, 21 (suppl. 11), 71.

5. Rosenfeld, R. S., and L. Hellman. Excretion of steroid acids in man. Arch. Biochem. 1962, 97, 406.

6. Miller, O. N., J. G. Hamilton, and G. A. Goldsmith. On the mechanism of action of nicotinic acid in lowering serum lipids. Amer. J. clin. Nutr. 1962, 10, 285.

7. Powell, R. C., W. T. Nunes, R. S. Harding, and J. B. Vacca. The influence of nonabsorbable antibiotics on serum lipids and the excretion of neutral sterols and bile acids. Amer. J. clin. Nutr. 1962, $11,156$.

8. Spritz, N., S. Grundy, and E. H. Ahrens, Jr. Studies on the mechanism of diet-induced alterations of plasma cholesterol (abstract). J. clin. Invest. 1963, 42, 981.

9. Engelberg, H. Short term studies of effect of heparin upon cholesterol excretion in man. Proc. Soc. exp. Biol. (N. Y.) 1959, 102, 365.

10. Spritz, N., E. H. Ahrens, Jr., and S. Grundy. Sterol balance in man as plasma cholesterol concentrations are altered by exchanges of dietary fats. J. clin. Invest. 1965, 44, 1482.

11. Hellman, L., R. S. Rosenfeld, W. Insull, Jr., and E. H. Ahrens, Jr. Intestinal excretion of cholesterol: a mechanism for regulation of plasma levels (abstract). J. clin. Invest. 1957, 36, 898.

12. Hellman, L., and R. S. Rosenfeld. Isotopic studies of cholesterol metabolism in man in Hormones and Atherosclerosis, G. Pincus, Ed. New York, Academic Press, 1959, p. 157.

13. Avigan, J., and D. Steinberg. Metabolism and excretion of cholesterol in man. Fed. Proc. 1959, 18, 5.

14. Sjövall, J. Separation and determination of bile acids in Methods of Biochemical Analysis, D. Glick, Ed. New York, Interscience, 1964, vol. 12, p. 97.

15. Bergström, S., H. Danielsson, and B. Samuelsson. Formation and metabolism of bile acids in Lipide Metabolism, K. Block, Ed. New York, John Wiley \& Sons, 1960, p. 291.

16. Danielsson, H., P. Eneroth, K. Hellström, S. Lindstedt, and J. Sjövall. On the turnover and excretory products of cholic and chenodeoxycholic acid in man. J. biol. Chem. 1963, 238, 2299.

17. Lindstedt, $\mathrm{S}$. The turnover of cholic acid in man. Acta physiol. scand. 1957, 40, 1.

18. Sperry, W. M., and M. Webb. A revision of the Schoenheimer-Sperry method for cholesterol determination. J. biol. Chem. 1950, 187, 97.

19. Stewart, C. P., and E. B. Hendry. The phospholipins of blood. Biochem. J. 1935, 29, 1683.

20. Bragdon, J. H. Colorimetric determination of blood lipides. J. biol. Chem. 1951, 190, 513.

21. Bergström, S., M. Rottenberg, and J. Voltz. The preparation of some carboxyllabeled bile acids. Acta chem. scand. 1953, 7, 481. 
22. Sjövall, J. The determination of bile acids in bile and duodenal contents by quantitative paper chromatography. Clin. chim. Acta 1959, 4, 652.

23. Eriksson, S., and J. Sjövall. The absorption spectra of conjugated bile acids in sulfuric acid. Arkiv Kemi 1955, 8, 311.

24. Bergström, S., and J. Sjövall. Separation of bile acids with reversed phase partition chromatography. Acta chem. scand. 1951, 5, 1267.

25. Norman, A. Separation of conjugated bile acids by partition chromatography. Acta chem. scand. 1953, $7,1413$.

26. Norman, A., and J. Sjövall. On the transformation and enterohepatic circulation of cholic acid in the rat. J. biol. Chem. 1958, 233, 872.

27. Glascock, R. F. Isotopic Gas Analysis for Biochemists. New York, Academic Press, 1954.

28. Hellström, K., and S. Lindstedt. Cholic-acid turnover and biliary bile-acid composition in humans with abnormal thyroid function. J. Lab. clin. Med. 1964, 63, 666.

29. Hellström, K., and S. Lindstedt. Studies on the formation of cholic acid in subjects receiving a standardized diet with butter or corn oil as dietary fat. Amer. J. clin. Nutr. In press.

30. Steinberg, D., and J. Avigan. Unpublished results.

31. Sjövall, J. Bile acids in man under normal and pathological conditions. Clin. chim. Acta 1960, 5, 33.

32. Sjövall, J. Dietary glycine and taurine on bile acid conjugation in man. Proc. Soc. exp. Biol. (N. Y.) 1959, 100, 676.

33. Hellström, K., and J. Sjövall. Conjugation of bile acids in patients with hypothyroidism. J. Atheroscler. Res. 1961, 1, 205.

34. Ekdahl, P. H. On the conjugation and formation of bile acid in the human liver. VI. On the conjugation of cholic acid-24 ${ }^{14} \mathrm{C}$ in human liver homogenates in various diseases with special reference to patients with jaundice. Acta chir. scand. 1955, 115, 208.

35. Eriksson, S. Influence of thyroid activity on excretion of bile acids and cholesterol in the rat. Proc. Soc. exp. Biol. (N. Y.) 1957, 94, 582.

36. Lin, T. H., R. Rubinstein, and W. L. Holmes. A study of the effect of $\mathrm{D}$ - and L-triiodothyronine on bile acid excretion of rats. J. Lipid Res. 1963, 4, 63.

37. Strand, O. Influence of propylthiouracil and D- and L-triiodothyronine on excretion of bile acids in bile fistula rats. Proc. Soc. exp. Biol. (N. Y.) 1962, 109, 668.

38. Norman, A., and J. Sjövall. Formation of lithocholic acid from chenodeoxycholic acid in the rat. Acta chem. scand. 1960, 14, 1815.

39. Hellström, K., and J. Sjövall. Metabolism of chenodeoxycholic acid in the rabbit. Acta chem. scand. 1960, 14, 1763.

40. Hellström, K., and J. Sjövall. On the origin of lithocholic and ursodeoxycholic acids in man. Acta physiol. scand. 1961, 51, 218.

41. Lindstedt, S., and J. Sjövall. On the formation of deoxycholic acid from cholic acid in the rabbit. Acta chem. scand. 1957, 11, 421.

42. Lindstedt, $S$. The formation of deoxycholic acid in man. Arkiv Kemi 1957, 11, 145.

43. Tidwell, H. C., J. C. McPherson, and W. W. Burr, Jr. Effect of the saturation of fats upon the disposition of ingested cholesterol. Amer. J. clin. Nutr. 1962, 11, 108.

44. Avigan, J., and D. Steinberg. Effects of saturated and unsaturated fat on cholesterol metabolism in the rat. Proc. Soc. exp. Biol. (N. Y.) 1958, 97, 814.

45. Greenbaum, B. W., J. R. Geary, Jr., F. Grande, J. T. Anderson, and D. Glick. Effect of dietary lipid on rat serum and liver cholesterol and tissue mast cells. Proc. Soc. exp. Biol. (N. Y.) 1957, 94, 613.

46. Brown, H. B., and L. A. Lewis. Effect of high fat and high protein diets on tissue lipids (abstract). Circulation 1956, 14, 488.

47. Bloomfield, D. K. Cholesterol metabolism. III. Enhancement of cholesterol absorption and accumulation in safflower oil-fed rats. J. Lab. clin. Med. 1964, 64, 613.

48. Wilson, J. D., and M. D. Siperstein. Effect of saturated and unsaturated fats on hepatic synthesis and biliary excretion of cholesterol by the rat. Amer. J. Physiol. 1959, 196, 599.

\section{SPECIAL NOTICE TO SUBSCRIBERS}

Post Offices will no longer forward the Journal when you move.

Please notify The Journal of Clinical Investigation, Business Office, 10 Stoughton Street, Boston, Mass. 02118, at once when you have a change of address, and do not omit the Zip Code number. 